University of Nebraska - Lincoln

DigitalCommons@University of Nebraska - Lincoln

USDA National Wildlife Research Center - Staff Publications
U.S. Department of Agriculture: Animal and Plant Health Inspection Service

2012

\title{
Feral swine disturbance at important archaeological sites
}

Richard M. Engeman

USDA-APHIS-Wildlife Services, s_r100@yahoo.com

Kathy J. Couturier

Avon Park Air Force Range

Rodney K. Felix Jr.

USDA, National Wildlife Research Center

Michael L. Avery

USDA, National Wildlife Research Center, michael.I.avery@aphis.usda.gov

Follow this and additional works at: https://digitalcommons.unl.edu/icwdm_usdanwrc

Engeman, Richard M.; Couturier, Kathy J.; Felix, Rodney K. Jr.; and Avery, Michael L., "Feral swine disturbance at important archaeological sites" (2012). USDA National Wildlife Research Center - Staff Publications. 1130.

https://digitalcommons.unl.edu/icwdm_usdanwrc/1130

This Article is brought to you for free and open access by the U.S. Department of Agriculture: Animal and Plant Health Inspection Service at DigitalCommons@University of Nebraska - Lincoln. It has been accepted for inclusion in USDA National Wildlife Research Center - Staff Publications by an authorized administrator of DigitalCommons@University of Nebraska - Lincoln. 


\title{
Feral swine disturbance at important archaeological sites
}

\author{
Richard M. Engeman • Kathy J. Couturier • \\ Rodney K. Felix Jr. • Michael L. Avery
}

Received: 22 October 2012 / Accepted: 22 November 2012

(C) Springer-Verlag Berlin Heidelberg (outside the USA) 2012

This article is a U.S. government work, and is not subject to copyright in the United States.

\begin{abstract}
Feral swine are well known as environmentally destructive invasive animals in many areas around the world, where they degrade native habitats, harm rare plant and animal species, damage agricultural interests, and spread disease. We provide the first quantification of their potential as agents of disturbance at archaeological sites. Our study was conducted in south-central Florida at Avon Park Air Force Range, a base comprising over 40,000 ha and containing many archaeological sites. To determine the identifiable prevalence of feral swine disturbance, we examined 36 sites registered with the Florida State Historic Preservation Office and also eligible for inclusion in the National Register of Historic Places (NRHP). Moreover, we evaluated the extent of swine disturbance at a prehistoric site of extraordinary significance to Florida's prehistory, "Dead Cow." Fifteen of the 36 NRHP-eligible sites (42\%) had some level of swine disturbance, including 14 of 30 (47\%) sites known to have artifacts within $20 \mathrm{~cm}$ of the surface (well within swine rooting depths). At the Dead Cow site, we documented disturbance at $74 \%$ of shovel test points. Sites with shallow artifact depositions appeared
\end{abstract}

Responsible editor: Philippe Garrigues

R. M. Engeman $(\bowtie)$

USDA, National Wildlife Research Center, 4101 LaPorte Ave,

Fort Collins, CO 80521-2154, USA

e-mail: richard.m.engeman@aphis.usda.gov

K. J. Couturier

Avon Park Air Force Range, 29 South Blvd,

Avon Park Air Force Range, FL 33825, USA

R. K. Felix Jr. • M. L. Avery

USDA, National Wildlife Research Center, Florida Field Station, 2820 East University Avenue,

Gainesville, FL 32641, USA

Present Address:

R. K. Felix Jr.

Eglin AFB Natural Resources-Wildlife, 107 SR 85 North,

Niceville, FL 32578, USA highly vulnerable to disturbance by feral swine, threatening destruction of artifact stratigraphy and provenience. Our observations likely are a minimal representation of accumulated damage. These irreplaceable sites tell the area's land use story across the millennia. That they are under threat from feral swine should serve broad notice of potential threats that feral swine may pose to archaeological sites globally, making effective swine management imperative for site protection.

Keywords Animal damage - Conservation · Feral hog · Invasive species · Provenience · Stratigraphy $\cdot$ Sus scrofa

\section{Introduction}

Feral swine (Sus scrofa) were first introduced to North America in Florida in the 1500s, and many subsequent intentional and accidental introductions have followed (Belden and Frankenberger 1977; Mayer and Brisbin 1991; Towne and Wentworth 1950). Today, feral swine flourish in the USA and are well known as particularly destructive invasive animals, as they degrade native habitats, harm rare plant and animal species, damage agricultural interests, and spread disease (e.g., Engeman et al. 2007; Corn et al. 2005; Seward et al. 2004). The species was listed among the 100 "World's Worst" invaders by the IUCN's Invasive Species Specialist Group (Lowe et al. 2004). The same rooting and wallowing behaviors so directly destructive to sensitive habitats and agriculture hold similar potential to directly damage archaeological sites. Moreover, further indirect damage may result because feral swine activity loosens the soil and accelerates erosion (Mungall 2001). Despite this destructive potential, there is little, if any, journal documentation quantifying prevalence of swine disturbance to archaeological sites on a regional basis or even quantifying the extent of swine disturbance within a single archaeological site. 
Florida was the initial foothold when Europeans began exploring the west. The European archives share stories of the rich cultures they found, and much archaeological evidence is still waiting to be revealed in the soils of Florida. Archaeological sites abound in Florida, as do invasive feral swine, which are ubiquitous throughout the state. Florida's wet environment and typically soft soil substrates render much of the landscape, and archaeological sites by extension, vulnerable to disturbance by feral swine. We conducted quantitative investigations of feral swine damage at archaeological sites by (1) studying the regional prevalence of swine damage to potential National Register of Historic Places (NRHP) archaeological sites at Avon Park Air Force Range (APAFR), a large property rich in archaeological sites from ancient to historical times; and (2) examining the extent of swine disturbance within a particularly significant site among those.

\section{Methods}

Study area

The APAFR is a ca. 42,930-ha Department of Defense training installation located in Polk and Highlands counties in central Florida, owned and operated by the U.S. Air Force. The base consists mostly of natural habitats used as military training areas, with over 33,000 ha open to the public on a regular basis for various recreational activities. The Air Force, as part of its federally mandated responsibilities, not only manages the natural resources of APAFR to support the military readiness mission but also to ensure the area's sustainability. Feral swine impacts on the base's natural resources, especially ecologically sensitive wetland habitats, is a management issue at APAFR (USDA/ Wildlife Services/National Wildlife Research Center 2011).

In addition to rare and sensitive habitats, APAFR includes hundreds of identified prehistoric and historic archaeological sites, with dozens potentially NRHP-eligible, although most have only been subject to an initial survey and remain largely unexcavated. We examined the subset of archaeological sites that are NRHP-eligible to quantify how widespread swine disturbance is among the important sites on the base, and we evaluated the extent of swine disturbance at one particularly important site, Dead Cow. Because our research involved no excavation or other disturbance to archaeological sites, no permits were required either from the military or under the auspices of the National Historic Preservation Act, and one member of our research team $(\mathrm{KC})$ is the base Cultural Resources Manager/Archaeologist. We purposefully avoid presenting specific location information for the archaeological sites to avert human disturbance at the sites.
Prevalence of damage among potential NRHP sites

From among the hundreds of archaeological sites at APAFR, we examined the subset of 36 sites that are NRHP-eligible. These sites, already registered with the Florida State Historic Preservation Office, were surveyed in October 2010 for swine rooting or other swine disturbance. The sites represented the wide diversity in types of archaeological sites in the region (Table 1). Of the 36 sites, 20 were prehistoric, eight were historic, and eight had both prehistoric and historic components. As is the case for most of APAFR, the archaeological sites are broadly characterized with sandy subsoils.

We located sites from existing GPS coordinates and inspected each for presence or absence of swine rooting, wallows, or trails. Swine damage was identified as ground overturned during foraging (rooting) activity (Engeman et al. 2004; USDA/Wildlife Services/National Wildlife Research Center 2011), while wallows are open depressions created by "rolling" activity of hogs (USDA/Wildlife Services/National Wildlife Research Center 2011). Tracks verified swine as the species responsible. Thorough descriptions of the types of feral swine damage found at APAFR are given in USDA/Wildlife Services/National Wildlife Research Center (2011). All observations were made by researchers experienced in studying feral swine damage.

Sites had been previously categorized according to whether they were prehistoric, historic, or had multicomponents, and for most sites, information was also available from shovel tests on the depths at which artifacts could be found. We were not only interested in whether there was swine disturbance at each site but also the depth of artifact deposits to further indicate each site's vulnerability to swine rooting. Thus, we also categorized each site in advance according to whether artifacts were known to occur within $10 \mathrm{~cm}$ of the surface and whether artifacts were known to occur within $20 \mathrm{~cm}$ of the surface. Of the 33 sites where artifact depths were defined, $79 \%$ (26) had artifacts within $10 \mathrm{~cm}$ of the surface and $91 \%$ (30) had artifacts within $20 \mathrm{~cm}$ of the surface. This allowed us to describe overall prevalence of swine damage to important archaeological sites at APAFR as well as within the different age categories and artifact depth categories.

Extent of damage within a significant prehistoric site

We evaluated spatial extent of swine disturbance across the most significant prehistoric cultural complex (Dead Cow) of the Okeechobee/Belle Glade archaeological area (Beasley III et al. 2009; Griffin et al. 2002). With deposits spanning five millennia, Dead Cow may redefine interpretation of the Florida Ridge cultural record (Beasley III et al. 2009; 
Table 1 Brief descriptions of the 36 archaeological sites on Avon Park Air Force Range eligible for the U.S. National Register of Historic Places that were examined for disturbance by feral swine

Site ID

Significance

Fort Kissimmee

Gaging Station

Orange Hammock

Sandy Hill Turpentine Camp

Dead Cow

\section{Air Force Mound \\ Dragline}

Morgan Hole Creek \#2

Big Jahn

Ft Kissimmee South

Borrow Canal

Marsh Trail Sill

Burnt Hammock

Small Nervosa

Psychotria Nervosa

Sandy Point Hammock

Bill Bay West

\section{Old Govt Railroad}

Scrub Jay

Zechiel Bell

J. Aiken Herty

Echo Range West Fence

Nalaka Turpentine Camp/Still
A significant site and location of Ft Kissimmee from Third Seminole War. Homesteads, school, church, and cemetery are in this area. Surface collection is substantial for the historic components of this site. There are also prehistoric resources buried deeper, but still in reach of swine rooting. This area was significant to the development of central Florida in cattle, lumber, and turpentine.

This area has an Indian mound still intact, but has only been superficially examined and needs further surveys.

This site is significant for historic and prehistoric remains. It also is part of the greater Homestead/Ft Kissimmee area and the development of the Kissimmee Island.

The Sandy Hill Turpentine Camp was a significant area for turpentine production where the turpentine was separated from the sap. It also joins a historic tramline.

This area has the most significant cultural complex on APAFR and holds the potential to change the way archaeology is viewed in central Florida. It also has a historic homestead on the complex that potentially may reveal life ways of cattle grazing, lumber, river traffic, and trade. There are historic and prehistoric human remains on the site, and vulnerable to swine damage.

Small Belle Glade midden that may be part of a complex with two other mounds in the area, but unexcavated.

This site is dated by a Simpson point $\geq 12,000$ years BP found through surface collection. This unexcavated site has the potential for excellent preservation of some of the oldest artifacts that can be found in Florida.

This site may possess important information regarding ceramic sequence and associated cultural chronology.

This is a recurring prehistoric camp location. This very wet area holds excellent potential for good artifact preservation. Continuous use of the site will likely further knowledge of prehistoric material culture, settlement patterns, and adaptive strategies in central Florida for the Archaic and Woodland periods.

The site has potential to provide valuable information on the region's prehistory, including an opportunity to examine an Archaic period site uncontaminated by artifacts from subsequent occupations (a relatively rare circumstance within the Kissimmee River basin). "Exotic" lithic material at the site may be the result of trade or a broad settlement and procurement system.

Data from this site could address numerous questions related to site-building and site-modification processes. Preserved ethnobotanical remains suggest that this site retains potential to yield data concerning paleo-ecology and subsistence.

This historic site with building remains could show important historic patterns of land use for homesteads.

The multi-component nature of this site holds vital information applicable to a wide array of geomorphic and archaeological research issues.

The site may provide information on the spatial distribution of Belle Glade Culture sites across the regional landscape and patterns of landscape usage from this time period. The only disturbances recorded at this site have been from swine.

A Belle Glade Habitation midden with shallow but dense cultural deposits. The site has the potential to reveal information on social and economic organization of the Belle Glade culture. Ear spool found on site is usually found in association with human remains, although they have not yet been found in this area.

A large base camp that was occupied during at least two discrete time periods. The deep concentration of material with diagnostic dart points may represent a discrete archaic period occupation. The site contains features tentatively identified as prehistoric earthworks, maybe adding variety and function of earthworks with chronological data that may help refine the regional ceramic sequence.

There is potential for stratigraphic separation of cultural materials. It may contain human remains, such as found in the Windover Pond and other sites in the region. This site may have been one of the only perennial sources of water in the area throughout the entire range of the Holocene. The site may contain extremely significant cultural deposits and has excellent research potential.

Old government railroad site that could yield information relevant to our understanding of material culture, transportation, and industrial and economic development in Florida at the turn of the 20th century.

This prehistoric site has artifact scatter and human remains.

A turpentine camp too near the base's impact zone to do invasive work. Further work must be done with non-invasive equipment for safety reasons.

Prehistoric campsite where further investigation is needed to determine Register eligibility.

High-density area of artifacts from prehistoric to historic turpentine camp and homesteads, with potential for land use research from prehistoric to historic.

Nalaka Turpentine Camp/Still is very significant to the history of central Florida and the Naval Stores. The site is only $0-20 \mathrm{~cm}$ deep and therefore at risk to swine disturbance. 
Table 1 (continued)

\begin{tabular}{|c|c|}
\hline Site ID & Significance \\
\hline Keene Dip Vat & $\begin{array}{l}\text { Keene site is a community dip vat and contributes to the knowledge of the ranching industry in Florida and is } \\
\text { unique because of the inscriptions on the dripping platform and its outlying structures. }\end{array}$ \\
\hline Nalaka Town & $\begin{array}{l}\text { Nalaka Town Site was a company town owned by Consolidated Naval Stores from } 1919 \text { to } 1928 \text {, an excellent } \\
\text { example of a turpentine-company-owned site. Most of the artifacts are on the surface and very vulnerable to } \\
\text { swine rooting. }\end{array}$ \\
\hline Barker & $\begin{array}{l}\text { A shell mound reflecting a specific facet of prehistoric subsistence strategies not commonly represented in the } \\
\text { Kissimmee or Okeechobee regions because they have been destroyed and often used for road fill. This site is } \\
\text { especially vulnerable to swine rooting. }\end{array}$ \\
\hline Eight Mile Hammock \#1 & $\begin{array}{l}\text { Minimally disturbed site with good internal stratification. The presence of unburned bone and soot-darkened } \\
\text { ceramics give good potential for radiocarbon dating. Site may be able to help refine regional chronology. }\end{array}$ \\
\hline Eight Mile Hammock \#2 & $\begin{array}{l}\text { Has potential to shed light on localized hydrological changes and associated cultural changes and may help to } \\
\text { refine local chronology. }\end{array}$ \\
\hline East Lavender & $\begin{array}{l}\text { Contains a variety of bone and ceramic artifact types in an essentially undisturbed context. Preservation of the } \\
\text { faunal remains is excellent; consequently, the site has great potential for contributing to an understanding of } \\
\text { prehistoric subsistence. The site has potential to contribute vital information concerning the ceramic chronology } \\
\text { of the region through dating of soot from vessels and cross-comparison of ceramic types. }\end{array}$ \\
\hline West Lavender & $\begin{array}{l}\text { The site appears to contain important information regarding changing subsistence strategies through time and } \\
\text { regarding functional vs. temporal variation in ceramics. There is an excellent record of Belle Glade adaptation } \\
\text { in this area (human remains found here too). The site contains an abundant and diverse faunal and ceramic } \\
\text { assemblage, which can provide important information on topics such as changing subsistence strategies } \\
\text { through time. }\end{array}$ \\
\hline Arbuckle Flatwoods & Prehistoric site with little data currently available. \\
\hline Ebersbach North & $\begin{array}{l}\text { A significant data base related to prehistoric settlement/subsistence strategies and extra-regional networks of } \\
\text { trade. The contextual integrity of the cultural deposits, coupled with the abundance of dateable organic remains, } \\
\text { allows for delineation of discrete spatial and temporal patterns. }\end{array}$ \\
\hline
\end{tabular}

Griffin et al. 2002). Moreover, a historic homestead on the complex could reveal life ways of cattle grazing, lumber, river traffic, and trade.

We used GPS coordinates from 19 shovel test grid locations within this site as observation points for swine disturbance. After locating each shovel test grid point by GPS, the observer recorded whether swine damage was visible within a 5-m radius of that point (which also was the halfway distance between adjacent grid points). We further recorded whether damage was $>10 \mathrm{~cm}$ in depth, and if any was $>20 \mathrm{~cm}$ in depth. We used the percent of shovel test points with damage as an estimate of the extent of damage within the site.

\section{Results}

Prevalence of damage among potential NRHP sites

Of the 36 NRHP-eligible sites observed, feral swine disturbance was observed within 15 (42\%) of them, including all age categories (Table 2). Half the 26 sites with artifacts $<10 \mathrm{~cm}$ of surface were rooted, and also 14 of $30(47 \%)$ with artifacts $<20 \mathrm{~cm}$ of surface. Thus, because swine rooting at APAFR commonly exceeds $30 \mathrm{~cm}$ in depth (USDA/ Wildlife Services/National Wildlife Research Center 2011) and the large majority (79\%) of archaeological sites had been identified as having artifacts within $10 \mathrm{~cm}$ of the surface, and almost all (91\%) had artifacts within $20 \mathrm{~cm}$ of the surface, the above prevalence of rooting indicated a large proportion of sites are at risk for direct swine damage to artifacts as well as disturbance of their stratigraphy and provenience.

Extent of damage within the significant prehistoric site

Swine rooting was observed in the vicinities of $74 \%$ (14 of 19) of shovel test points within the Dead Cow site. Another $21 \%$ (4 of 19) of shovel test observation points had no swine rooting, but had adjacent game trails, which are used

Table 2 Distribution by age category of feral swine disturbance among 36 archaeological sites on Avon Park Air Force Range eligible for the U.S. National Register of Historic Places

\begin{tabular}{lll}
\hline Age category & Number observed & $\begin{array}{l}\text { Number with swine } \\
\text { disturbance }(\%)\end{array}$ \\
\hline Prehistoric & 20 & $8(40 \%)$ \\
$\begin{array}{l}\text { Historic } \\
\begin{array}{l}\text { Prehistoric and historic } \\
\text { components }\end{array}\end{array}$ & 8 & $2(25 \%)$ \\
Total & 36 & $5(62.5 \%)$ \\
\hline
\end{tabular}




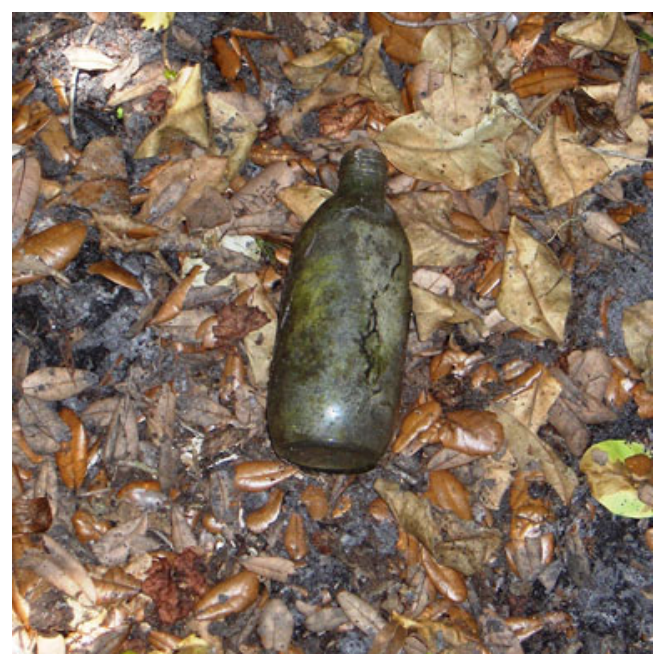

Fig. 1 Bottle rooted to the surface by feral swine at a historic archeological site in Florida

by swine and may induce/accelerate erosion at the site. Because the area is characterized by sandy soils and receives abundant rain, erosion can happen quickly while rooting scars can be rapidly smoothed from their original appearance and depth. Nevertheless, $14 \%$ (2 of 14) of the shovel test points with rooting had scars $10-20 \mathrm{~cm}$ in depth. This is also one of the sites with artifacts within $10 \mathrm{~cm}$ of the surface. Thus, this important site vital to interpretation of regional prehistory and history appeared highly attractive for rooting by feral swine and at considerable risk for swine to directly destroy artifacts or their stratigraphy and provenience.

\section{Discussion}

Our observations provide an assessment of risk potential for feral swine to harm the area's archaeological sites. We found widespread potential for artifact damage or displacement by feral swine because a large majority (79 \%) of the sites had artifacts near the surface, and a substantial portion of studied sites had disturbance by feral swine (42\%). While $50 \%$ of sites having artifacts within $10 \mathrm{~cm}$ of the surface and $47 \%$ of sites having artifacts within $20 \mathrm{~cm}$ of the surface showed swine disturbance, the other undisturbed sites with shallow artifact depositions are still vulnerable to future swine activity. Our sites were largely unevaluated archaeologically, and it was not in our purview to specifically examine for artifact destruction or displacement. Yet, during our investigation we could not help but observe areas where artifacts had been rooted to the surface (e.g., Fig 1). The extent of swine activity within Dead Cow, coupled with its importance and vulnerability, was alarming. Existing disturbance, this site's vulnerability for continued disturbance, and the archaeological importance of the site prompted the construction of a fence around it to preserve its integrity. Considering its $\$ 18,000$ USD cost, this remedy is likely fiscally impossible for general application.

In recent years, swine at APAFR have been targeted for population reductions to protect rare and sensitive wetland plant communities, and swine population indices have trended downwards (USDA/Wildlife Services/National Wildlife Research Center 2011). Quantification of swine disturbance at archaeological sites should elevate awareness of the broad risk potential posed by feral swine, thereby forming a basis for taking preservation actions. Reducing swine numbers likely will benefit archaeological site preservation by reducing (but not eliminating) agents of disturbance.

Swine rooting in Florida can be washed to obscurity or become overgrown and unrecognizable. The observed damage represents what was currently detectable, making it a minimal representation of accumulated damage. These irreplaceable sites tell the area's land use story across the millennia. They are under threat from an invasive animal species and effective management is imperative to reduce risks to archaeological sites.

\section{Conclusion}

It is likely that archaeological sites around the world in areas populated by wild swine also suffer disturbance from their activities. Our quantification of swine disturbance in a broad area in Florida should serve notice of the potential for swine damage to irreplaceable archaeological resources and should also help fortify management actions towards swine beyond the well-established but important objectives of protecting sensitive habitats, species, and agriculture, and deterring the threat of disease spread.

Acknowledgment We thank W.E. Bruce for assistance with observations in the field.

\section{References}

Beasley III VR, Shepard CJ, Pettitt A, Gill M, Torell, B (2009) Avon Park Air Force Range. Phase I Survey of Selected Areas and Phase II Testing at Sites 8 HG20/8HG27, 8PO1007, and 8PO6084, 2008-2009. U.S. Air Force Air Combat Command Series: Reports of Investigations Number 62. 196p

Belden RC, Frankenberger WG (1977) Management of feral hogs in Florida - past, present, and future. In: Wood GW (ed) Research and management of wild hog populations. Clemson University, Georgetown, pp 5-10

Corn JL, Cumbee JC, Chandler BA, Stallknecht DE, Fischer JR (2005) Implication of feral swine expansion: expansion of feral swine in the United States and potential implication for domestic swine. In: Feral Swine Subcommittee on Brucellosis and Pseudorabies. United States Animal Health Association, St. Joseph, pp 295-297 
Engeman RM, Smith HT, Severson R, Severson MA, Woolard J, Shwiff SA, Constantin BU, Griffin D (2004) Damage reduction estimates and benefit-cost values for feral swine control from the last remnant of a basin marsh system in Florida. Environ Conserv 31:207-211

Engeman RM, Stevens A, Allen J, Dunlap J, Daniel M, Teague D, Constantin BU (2007) Feral swine management for conservation of an imperiled wetland habitat: Florida's vanishing seepage slopes. Biol Conserv 134:440-446

Griffin JW, Milanich JT, Miller JJ (2002) Archaeology of the Everglades. University Press of Florida, Gainesville

Lowe S, Browne M, Boudjelas S, De Poorter M (2004) 100 of the world's worst invasive alien species: a selection from the Global Invasive Species Database. Invasive Species Specialist Group, Auckland
Mayer JJ, Brisbin IL (1991) Wild pigs in the United States. University of Georgia Press, Athens

Mungall EC (2001) Exotics. In: Demarais S, Krausman PR (eds) Ecology and management of large mammals in North America. Prentice Hall, Upper Saddle River, pp 736-764

Seward N, VerCauteren K, Witmer G, Engeman RM (2004) Feral swine impacts on agriculture and the environment. Sheep Goat Res J 19:34-40

Towne CW, Wentworth EN (1950) Pigs from cave to cornbelt. University of Oklahoma Press, Norman

USDA/Wildlife Services/National Wildlife Research Center (2011) Development, Implementation and evaluation of management tools to reduce feral swine damage at Avon Park AFR, Florida. Annual Report to U.S. DoD/Avon Park Air Force Range. USDA/ Wildlife Services/National Wildlife Research Center, Fort Collins 